\title{
Article \\ The Effect of Yellow Tea Leaves Camellia sinensis on the Quality of Stored Chocolate Confectionery
}

\author{
Anna Gramza-Michałowska *(D), Bartosz Kulczyński, Marta Skopiec, Joanna Kobus-Cisowska \\ and Anna Brzozowska
}

check for updates

Citation: Gramza-Michałowska, A.; Kulczyński, B.; Skopiec, M.;

Kobus-Cisowska, J.; Brzozowska, A. The Effect of Yellow Tea Leaves Camellia sinensis on the Quality of Stored Chocolate Confectionery. Appl. Sci. 2021, 11, 4123. https://doi.org/ 10.3390/app11094123

Academic Editor:

Wojciech Kolanowski

Received: 28 March 2021

Accepted: 27 April 2021

Published: 30 April 2021

Publisher's Note: MDPI stays neutral with regard to jurisdictional claims in published maps and institutional affiliations.

Copyright: (c) 2021 by the authors. Licensee MDPI, Basel, Switzerland. This article is an open access article distributed under the terms and conditions of the Creative Commons Attribution (CC BY) license (https:// creativecommons.org/licenses/by/ $4.0 /)$.
Department of Gastronomy Science and Functional Foods, Faculty of Food Science and Nutrition, Poznań University of Life Sciences, Wojska Polskiego 31, 60-624 Poznań, Poland; bartosz.kulczynski@up.poznan.pl (B.K.); marta.skopiec@up.poznan.pl (M.S.); joanna.kobus-cisowska@up.poznan.pl (J.K.-C.); anna.brzozowska@up.poznan.pl (A.B.)

* Correspondence: anna.gramza@up.poznan.pl; Tel.: +48-61-848-7327

Featured Application: The application of yellow tea components in confectionery indicates a new direction in functional foods' design process as it influences the antioxidant activity, sensory value and health promoting value of the final product.

Abstract: Chocolate and tea leaves are considered the most valuable sources of highly bioactive polyphenols due to their potential anti-cancer properties and beneficial effects on the cardiovascular and nervous systems. The objective of the present study was the development of a sensory profiling modality that is correlated with the taste of the chocolate enriched with yellow tea phytochemicals. The additive concentration was optimized in white chocolate and the designed product was evaluated using the sensory profiling method. It was shown that the yellow tea extract in chocolate had a significant effect on the taste and color of the product. Addition of $2.0 \%$ yellow tea powdered extract increased the value of color acceptance and caused an intensification of the aromas, particularly the leafy taste, compared to the control samples. The next step of the study was to determine the influence of tea addition in white, milk and dark chocolate subjected to 6 months of storage. The designed chocolates were tested for their activity as antioxidants (DPPH, ABTS and ORAC assay) and cholinesterase inhibitors (AChE, BChE assay). It was confirmed that the yellow tea addition affected the activity of prepared chocolates with respect to radical scavenging activity and was highest for dark chocolate with yellow tea where the values were as follows: $4373 \mathrm{mg}$ Tx/100 $\mathrm{g}$ (DPPH), $386 \mathrm{mg}$ Tx/100 $\mathrm{g}$ (ABTS) and $4363 \mu \mathrm{M} \mathrm{Tx} / 100 \mathrm{~g}$ (ORAC). An increase in the anti-radical activity of chocolate with yellow tea was found after 3 months of storage, but the subsequent 3 months of storage resulted in its reduction. AChE values ranged from 0.118 to 0.730 [ $\mu \mathrm{M}$ eserine $/ \mathrm{g} \mathrm{dw}$ ] and from 0.095 to $0.480[\mu \mathrm{M}$ eserine $/ \mathrm{g} \mathrm{dw}$ ] for BChE assay. Total capacity to inhibit AChE and BChE differed depending on the type of chocolate and was negatively influenced by the half-year storage. Summarizing tested values for individual samples were higher, with increasing content of cocoa liquor and yellow tea extract in the product. The results of the research show that the use of yellow tea in confectionery is promising and may appoint a new direction in functional foods.

Keywords: chocolate; Camelia sinensis; yellow tea; antioxidants; cholinesterase; radicals

\section{Introduction}

The beginning of the 21st century is characterized by a sudden increase in the number of people suffering from excessive oxidative stress. This could be related to, among others, a large intake of sweets and confectionery and a decrease in the consumption of polyphenol-rich foods [1,2]. Results showed that Western Europe and the United States citizens consume the highest amount with nearly $9 \mathrm{~kg} / \mathrm{y}$ in Switzerland and $4.3 \mathrm{~kg} / \mathrm{y}$ in the United States [3]. Due to the fact that the consumer does not want to give up the pleasure 
of eating certain products, food technologists design various types of food enriched with bioactive substances, or modify the composition of the products. Therefore, the production of chocolate with the addition of plant components is worth considering [4].

Results of much research showed that chocolate appears to increase positive mood, when it is eaten mindfully and that it can be enhanced with intention [5-8]. Chocolate's popularity has increased, along with the consumption of healthy snacks and confectioneries including probiotics, prebiotics and high phenolic content components [9-13]. This product is characterized by a low or medium glycemic index, depending on the product recipe, and exceptional presence of bioactive substances such as polyphenols, e.g., flavonoids such as catechins and notably, procyanidins, lipids, dietary minerals and methylxanthines [14-16]. Chocolate as functional food or nutraceutical is due to the positive relationship between its consumption and its effect upon health. Chocolate containing cocoa in its composition has many health-promoting properties, including reduced risk of cardiovascular disease, osteoporosis, cancer, neurodegenerative and central nervous system disorders, diabetes, obesity and metabolic syndrome [15,17-20].

Cocoa, a major chocolate ingredient, has the highest flavanol content among foods and contributes to higher flavonoid intake than tea or fruits and vegetables [18]. Therefore, tea leaves (Camellia sinensis) beverages are the most popular that are widely consumed by humans and well known for their beneficial properties [21,22]. They have been reported to be the beverage with some of the highest antioxidant content [23], depending on tea kind and processing conditions [24-27]. One of the most important compounds that exhibit biological activities with significantly strong antioxidant activity are plant polyphenols. The main antioxidants present in tea are flavonoids and phenolic acids, whose high content influences the consumers health and food products shelf life. Numerous studies reported that regular intake of tea components is associated with an improved antioxidant status in vivo conditions. Systematic delivery of substances with high antioxidant potential may contribute to the lowering risk of coronary heart disease, stroke, atherosclerosis, certain types of cancer, increasing insulin sensitivity properties, and protection against inflammation, bacteria or neurodegenerative diseases [22,28-33].

Health-promoting properties of chocolate and tea components are well known, nevertheless, the deteriorating environmental conditions that cause significant stress to the human body have resulted in the increased interest in the functional food. The food market offer has increased significantly, especially considering the snacks enriched with bioactive components from the so-called superfood. Previous research reported the influence of consumer attitudes towards healthy food choices and purchase intentions [34]. Consumer attitudes toward product-related information are important factors to consider because they will determine the acceptance of food products, and the final decision of product purchase.

The consumer's need to live a healthy life increased an interest in food with the addition of tea components, mainly green, among which the confectionery products are the most popular and well-studied. Tea confectionery products include, but are not limited to, donuts, cookies, biscuits, popsicle, candies, bars, ice cream, milk and white chocolate, chewing gum or jelly candies, thereby giving the consumer a healthier product with the desired quality and sensory value [35-46]. The literature describes in detail the antioxidant and free radical scavenging properties as well as the antimutagenic properties that characterize the extracts of all types of tea and chocolates. Therefore, the subject of this work is chocolate, a popular product willingly and often chosen by consumers, which for the first time has been combined with yellow tea aqueous extract to increase the antioxidant and health-promoting potential of the designed product. The objective of the present study was to develop a sensory profiling modality that is correlated with the taste of the chocolate enriched with yellow tea phytochemicals, its chemical composition and antioxidant activity. 


\section{Materials and Methods}

\subsection{Sample Preparation}

The research material was commercially available: yellow tea leaves Camellia sinensis, cultivar China Kekecha (Guangzhou province, China, supplied by Gemini, Poland) and chocolate (Belcolade, Belgium), a high quality product offered on the market for a wide variety of applications in the bakery, patisserie and chocolate sectors. Therefore, tested samples were an innovative confectionery product, which consisted of white, milk and dark chocolate to which powdered yellow tea extract was added. The yellow tea (Camellia sinensis, var. Kekecha) aqueous extract was prepared according to previously published procedure [47]. Briefly, $100 \mathrm{~g}$ of dried tea leaves were ground and extracted with $\mathrm{ddH}_{2} \mathrm{O}$ at $80^{\circ} \mathrm{C}$ for $15 \mathrm{~min}$. Then, the extract was filtered and lyophilized to produce the powdered extract which was kept frozen and further analyzed.

Initially, chocolate callets were subjected to a tempering process, which is essential for obtaining desired hardness, shine and breaking characteristics. The process involved the pre-crystallization of the cocoa butter in the chocolate, thereby transforming it into a stabile crystalline form. After tempering, the powdered yellow tea extract was added, then the chocolate was crystalized and subjected to sensory evaluation. The scheme of the conducted research is presented on Figure 1.

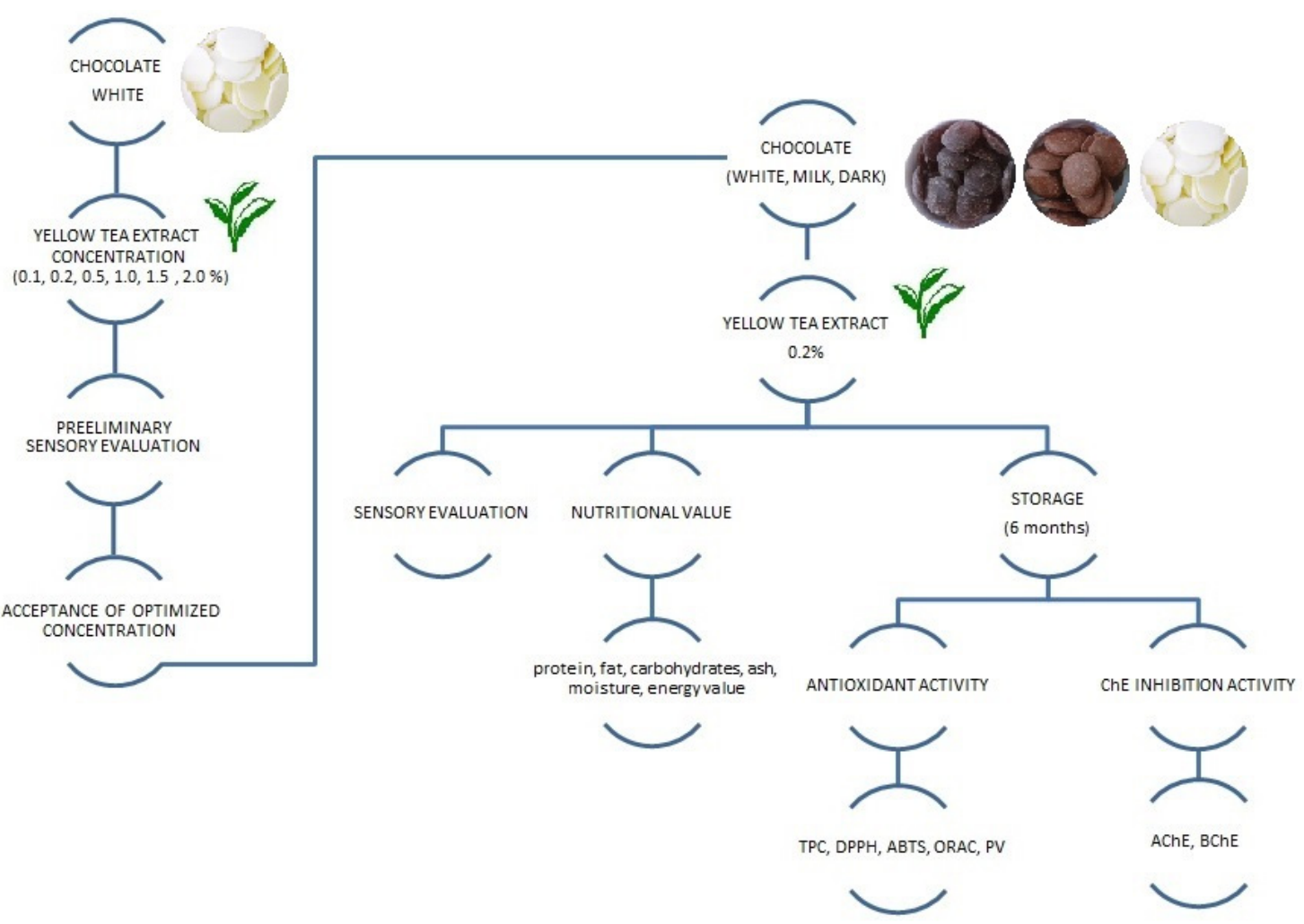

Figure 1. Scheme of the conducted research.

\subsection{Preliminary Sensory Evaluation}

In the first stage of the research, sensory analyses were carried out in order to select the most acceptable concentration of yellow tea extract addition to chocolate. Commercially available white chocolate callets were used as a carrier due to their low aroma and light color compared to chocolates containing cocoa liquor. A total of seven concentrations of tea extract used for different features were: $0.0 \%, 0.1 \%, 0.2 \%, 0.5 \%, 1.0 \%, 1.5 \%$, and $2.0 \%$ according to chocolate dry mass. These selected samples were prepared by adding the respective mass of tea extract to $100 \mathrm{~g}$ of white chocolate (Belcolade, Belgium). The chocolate was tempered using a chocolate melting pot (Hendi, Poland) while stirring until 
it reached $40-42{ }^{\circ} \mathrm{C}$, then the powdered tea extract was added and thoroughly mixed until a smooth and homogeneous consistency. Then, enriched chocolate was poured into round molds and kept in a cooler at $4{ }^{\circ} \mathrm{C}$ for 20 min to solidify. Consumer assessment of aroma, color, taste, texture and overall acceptability was carried out in the sensory evaluation laboratory [48]. The developed chocolate samples were evaluated in a focus group $(n=10$ of sensory trained professionals from The University of Life Sciences in Poznań) to select the most acceptable concentration of tea extract based on sensory descriptors intensity [49]. Participants were given two pieces of coded samples of chocolate from each extract's concentration and were asked initially to identify the intensity of taste. Evaluation was conducted under red light in order to mask color differences between food samples and avoid sample color suggestion. Once identified, they had to rate the sensory evaluation criteria of aroma, color, taste, texture and overall acceptability on a 10-point hedonic scale with boundary indications: "I do not like it extremely" (1) to "I like it extremely" (10). Finally, the most liked samples out of seven concentrations for yellow tea extract were selected for further analyses. The data were expressed as the medians of all the scores.

\subsection{Proper Sensory Evaluation}

In the second stage of the research, sensory analyses were carried out in order to evaluate the most acceptable chocolate with addition of yellow tea extract in a concentration receiving the highest acceptability in a preliminary sensory evaluation. For the research, $0.2 \%$ addition of yellow tea extract was chosen and subjected to further analyses. White (WCC), milk (MCC) and dark chocolate (DCC) (Belcolade, Belgium) were subjected to tempering process (white $38^{\circ} \mathrm{C}$, milk $40^{\circ} \mathrm{C}$ and dark $43^{\circ} \mathrm{C}$ ). After tempering, the powdered yellow tea extract was added and thoroughly mixed in order to receive the homogenous consistency and tea extract's even dispersion. As a result, white (WCT), milk (MCT) and dark (DCT) chocolates with the addition of yellow tea extract were prepared. Next, enriched chocolate was poured into shaped molds and left to crystalize during $12 \mathrm{~h}$, at $16-18{ }^{\circ} \mathrm{C}$ with an average humidity below $60 \%$, then stored in a dark place at $18{ }^{\circ} \mathrm{C}$ in order to solidify. Consumer assessment of aroma, color, taste, texture and overall acceptability was carried out in the sensory evaluation laboratory and evaluated in a focus group $(n=20$ of sensory trained consumers) using the scaling method [50]. Participants were given two pieces of coded samples of each kind of chocolate with yellow tea extract and were asked to rate the sensory evaluation criteria of aroma, color, taste, texture and overall acceptability on a 10-point hedonic scale with boundary indications: "I do not like it extremely" (1) to "I like it extremely" (10).

\subsection{Chemical Composition}

The basic chemical composition of the chocolates with yellow tea leaves extract included total fat, protein, ash, moisture and carbohydrate content. Total fat content was determined with the Soxhlet method using Soxtec-HT6 System (Foss Tecator, Hoganas, Sweden) [51], the protein content was determined by the Kjeldahl method using Kjeltec2200 System (Foss Tecator, Sweden) [52], the ash content was determined after samples complete burning in an oven [53]. The total carbohydrates content was calculated according to using the equation: total carbohydrates $=100-($ fat + protein + water + ash $)$. Energy value of chocolates was evaluated according to [54].

\subsection{Sample Extraction Procedure}

Chocolate samples (20 g) were subsequently extracted using a three-step extraction procedure (ASE 350 Dionex, Thermo Fisher Scientific, Waltham, MA, USA). In the first step, the sample was extracted with $40 \mathrm{~mL}$ of chloroform for 20 min cycle on a multirotator $(300 \mathrm{rpm})$. Then, $40 \mathrm{~mL}$ of $60 \%$ methanol was added and extracted for $30 \mathrm{~min}$ (the process was repeated). The supernatants were filtered (Whatman 1:11 $\mu \mathrm{m}$ ), and centrifuged (1.5 min, $2697 \mathrm{~g})$. Then, the fat and protein layers were separated. The sample was washed once again with chloroform in an amount of $1 / 4$ of the volume of the resulting solution. 
The solution was subjected to the centrifugation process again. After collecting the upper layer, the supernatant was placed in a rotary evaporator to remove remaining chloroform. Then, the extracts were combined and stored in a dark, cool place prior to further analysis of total phenolic content, DPPH, ABTS radical scavenging activity, ORAC, chelating activity, $\mathrm{AChE}$ and BChE.

\subsection{Total Phenolic Content}

The amount of total phenolics (TPC) in the chocolates was determined using FolinCiocalteau colorimetric assay [55] and expressed as catechin equivalent (C) in mg per $100 \mathrm{~g}$ product of powder, using the calibration curve over the range of $0-600 \mathrm{mg} / \mathrm{mL}$ $\left(y=2.4797 \times-0.0039, R^{2}=0.9936\right)$.

\subsection{Antioxidant Activity}

DPPH radical scavenging activity: The analysis was carried out using the DPPH radical scavenging assay [56]. The DPPH radical scavenging activity was expressed as Trolox equivalent $(\mathrm{Tx})$ in $\mathrm{mg}$ per $100 \mathrm{~g}$ of product, using the calibration curve over the range of $0-1 \mathrm{mg} / \mathrm{mL}\left(y=334.81 \times, \mathrm{R}^{2}=0.9636\right)$.

ABTS cation radical scavenging activity: The analysis was carried out using the ABTS radical cation decolorization assay [57]. The ABTS radical cation scavenging activity was expressed as Trolox equivalent (Tx) in mg per $100 \mathrm{~g}$ of product, using the calibration curve over the range of $0-1 \mathrm{mg} / \mathrm{mL}\left(y=182.97 \times, R^{2}=0.9953\right)$.

ORAC activity: Oxygen Radical Absorbance Capacity Assay (ORAC) was assayed using a method described by Gramza-Michałowska et al. [58]. Results were expressed as $\mu$ mol of Trolox equivalents (Tx) per $100 \mathrm{~g}$ of product, using the calibration curve over the range of $0-120 \mu \mathrm{mol}\left(y=0.2697 \times+1.1888, R^{2}=0.9834\right)$.

Peroxide value $(P V)$ : The influence of additives on lipid oxidation stability was measured according to PN-EN ISO 3960: 2009 [59].

\subsection{Cholinesterase Inhibition}

The activity of the chocolate with yellow tea extracts as acetylcholinesterase (AChE) and butyrylcholinesterase (BChE) inhibitors was assayed using a method described by Ellman et al. [60] and with modification of Kobus-Cisowska et al. [61]. Results were expressed as $\mu \mathrm{mol}$ of eserine equivalents per $1 \mathrm{~g}$ of a product, using the calibration curve over the range of 0.09-6.10 $\mu \mathrm{M}$ for $\mathrm{AChE}$ and $0.09-8.57 \mu \mathrm{M}$ for BChE.

\subsection{Statistical Analysis}

All experiments were performed in triplicate and the results are mean SD. Data were analyzed using one-way analysis of variance (ANOVA), followed by Tukey's post-hoc test. The significance level of statistical differences was calculated at $p<0.05$ and marked by superscript letters. All statistical analyses were performed using Statistica 13.3 software (StatSoft, Kraków, Poland).

\section{Results}

\subsection{Optimization of Yellow Tea Extract Concentration in Confectionery}

The process of sensory optimization allowed for the production of chocolates enriched with plant extract, which were subjected to qualitative analyses in subsequent stages of the work. To determine the concentration of the additive with highest acceptation of the consumers, a series of enriched chocolate products sensory analyses were conducted. The research was preceded by the evaluation of sensory acceptance of white chocolate with a sequence of yellow tea extract six concentrations $0.1,0.2,0.5,1.0,1.5$ and $2.0 \%$. Consumer assessment of formulated chocolates included such features as: aroma, color, taste, texture and overall acceptability (Figure 2). In the scaling method assessment of the investigated factors, the highest grade was characterized by chocolate with $0.2 \%$ addition of yellow tea extract, while the lowest with $2.0 \%(\mathrm{~m} / \mathrm{m})$. The aroma, color, texture and 
overall acceptability were evaluated with highest scores compared to other concentrations of yellow tea extract. Based on the above results, a $0.2 \%$ concentration of the yellow tea extract was selected for subsequent testing, which was applied in white, milk and bitter chocolate samples.

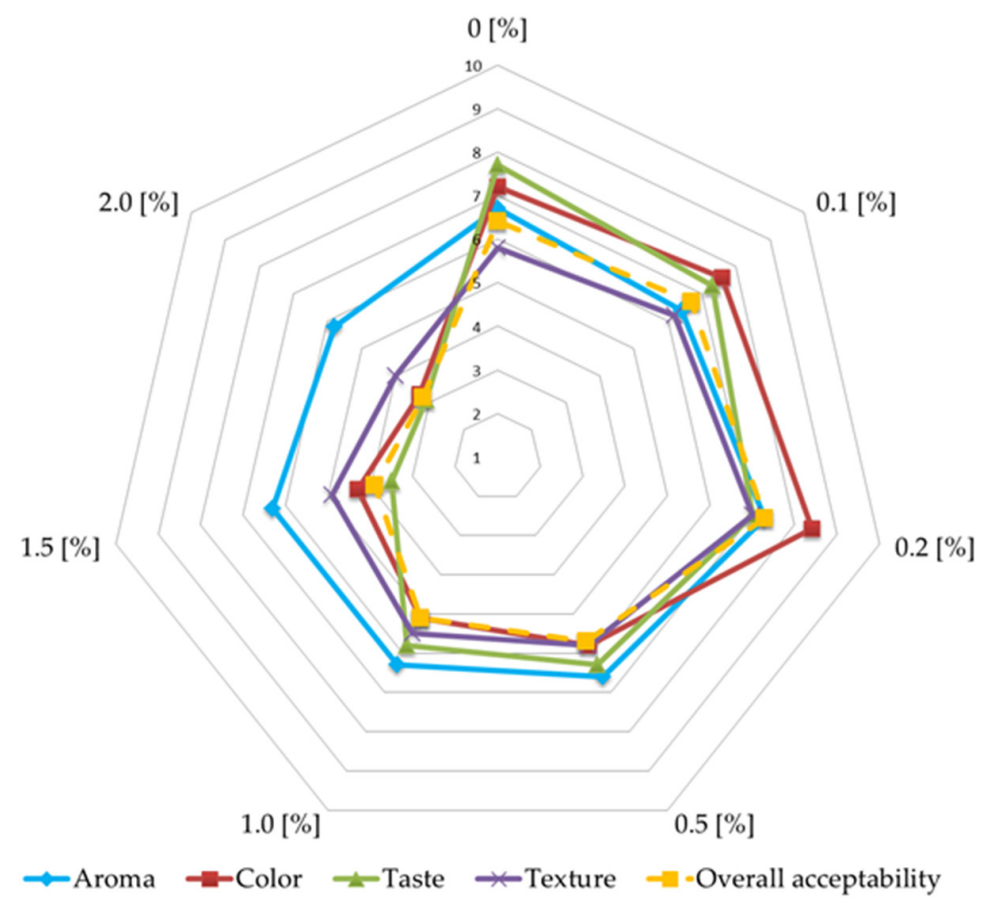

Figure 2. Sensory analysis of white chocolate with the addition of yellow tea extract in different concentrations $(0.1-2.0 \%)$.

\subsection{Basic Chemical Composition of Designed Confectionery}

Following the optimization process, white, milk and dark chocolates were mixed with a selected concentration of powdered yellow tea extract to evaluate the sensory attributes and antioxidant activity of obtained confectionery. The composition and total polyphenols content of chocolates are presented in Table 1. Analysis of the basic chemical composition of confectionery without and with the fortification of yellow tea extract did not differ within total fat, protein, ash and carbohydrates content. The differences have been noticed between the type of chocolates, which mainly resulted from different proportions of fat, sugar, cocoa and milk. As expected, white and milk chocolates were of slightly highest energy value, while dark one was the lowest. It was found that functional additive accounting for $0.2 \%$ of dry mass of chocolates did not influence the basic chemical composition, however, it significantly influenced total polyphenols content (TPC) in samples with yellow tea extract addition $(p<0.05)$. The average content of TPC in samples with $0.2 \%$ of yellow tea extract increased by $180 \%$ for white chocolate (WCT), $70 \%$ for milk (MCT) and $40 \%$ for dark chocolate (DCT) in comparison to control samples of chocolates with no additives. 
Table 1. Basic chemical composition of designed chocolates.

\begin{tabular}{|c|c|c|c|c|c|c|c|}
\hline Component & Unit & WCC & WCT & MCC & MCT & DCC & DCT \\
\hline Total fat & {$[\mathrm{g} / 100 \mathrm{~g}]$} & $29.74 \pm 0.36^{a}$ & $28.43 \pm 0.41^{\mathrm{a}}$ & $31.98 \pm 0.97^{a}$ & $32.29 \pm 2.55^{a}$ & $28.53 \pm 0.24^{a}$ & $27.98 \pm 1.35^{\mathrm{a}}$ \\
\hline Protein & {$[\mathrm{g} / 100 \mathrm{~g}]$} & $5.96 \pm 0.06^{\mathrm{a}}$ & $5.99 \pm 0.12^{\mathrm{a}}$ & $7.78 \pm 0.032^{c}$ & $7.66 \pm 0.09^{c}$ & $6.75 \pm 0.15^{b}$ & $6.52 \pm 0.24^{b}$ \\
\hline Ash & {$[\mathrm{g} / 100 \mathrm{~g}]$} & $1.36 \pm 0.01^{\mathrm{a}}$ & $1.37 \pm 0.02^{\mathrm{a}}$ & $1.86 \pm 0.01^{c}$ & $1.87 \pm 0.01^{\mathrm{c}}$ & $1.76 \pm 0.03^{b}$ & $1.73 \pm 0.02^{b}$ \\
\hline Carbohydrates & {$[\mathrm{g} / 100 \mathrm{~g}]$} & $61.97 \pm 0.27^{\mathrm{ab}}$ & $63.41 \pm 0.19^{b}$ & $57.08 \pm 0.21^{\mathrm{a}}$ & $57.46 \pm 0.21^{a}$ & $61.91 \pm 0.18^{\mathrm{ab}}$ & $62.19 \pm 0.19^{b}$ \\
\hline Moisture & {$[\mathrm{g} / 100 \mathrm{~g}]$} & $0.95 \pm 0.01^{b}$ & $0.79 \pm 0.01^{\mathrm{a}}$ & $1.29 \pm 0.02^{c}$ & $1.71 \pm 0.01^{\mathrm{e}}$ & $1.32 \pm 0.02^{\mathrm{c}}$ & $1.56 \pm 0.02^{\mathrm{d}}$ \\
\hline Enerov va & {$[\mathrm{kcal} / 100 \mathrm{~g}]$} & 539 & 533 & 547 & 542 & 528 & 526 \\
\hline Energy va & {$[\mathrm{kJ} / 100 \mathrm{~g}]$} & 2255 & 2231 & 2286 & 2265 & 2212 & 2203 \\
\hline TPC & {$[\mathrm{mg} \mathrm{C} / 100 \mathrm{~g}]$} & $311.80 \pm 1.24^{\mathrm{a}}$ & $882.15 \pm 2.15^{c}$ & $764.25 \pm 3.01^{b}$ & $1269.95 \pm 5.01^{\mathrm{d}}$ & $1791.32 \pm 4.92^{\mathrm{e}}$ & $2424.13 \pm 3.28^{f}$ \\
\hline
\end{tabular}

Results are mean values of three determinations \pm SD; values sharing the same letter in verse are not significantly different $(p>0.05)$. Abbreviations: white chocolate control (WCC), white chocolate with tea (WCT), milk chocolate control (MCC), milk chocolate with tea (MCT), dark chocolate control (DCC), dark chocolate with tea (DCT), total polyphenols content (TPC), catechin (C).

\subsection{Sensory Analysis of Designed Confectionery}

Consumer perception of a food product should be regarded as a key strategy in the development of innovative food products. That is why white, milk and dark chocolate was chosen to reflect their ability to mask the sensory properties of a yellow tea extract. Next, the chocolates were subjected to consumer analysis, which covered quality-related properties including visual properties (color uniformity, color, surface), sensory attributes (aroma, taste, mouthfeel), and overall acceptability. The sensory panel scores are presented in Figure 3. Results showed that the yellow tea extract addition increased the value of color acceptance significantly $(p<0.05)$.

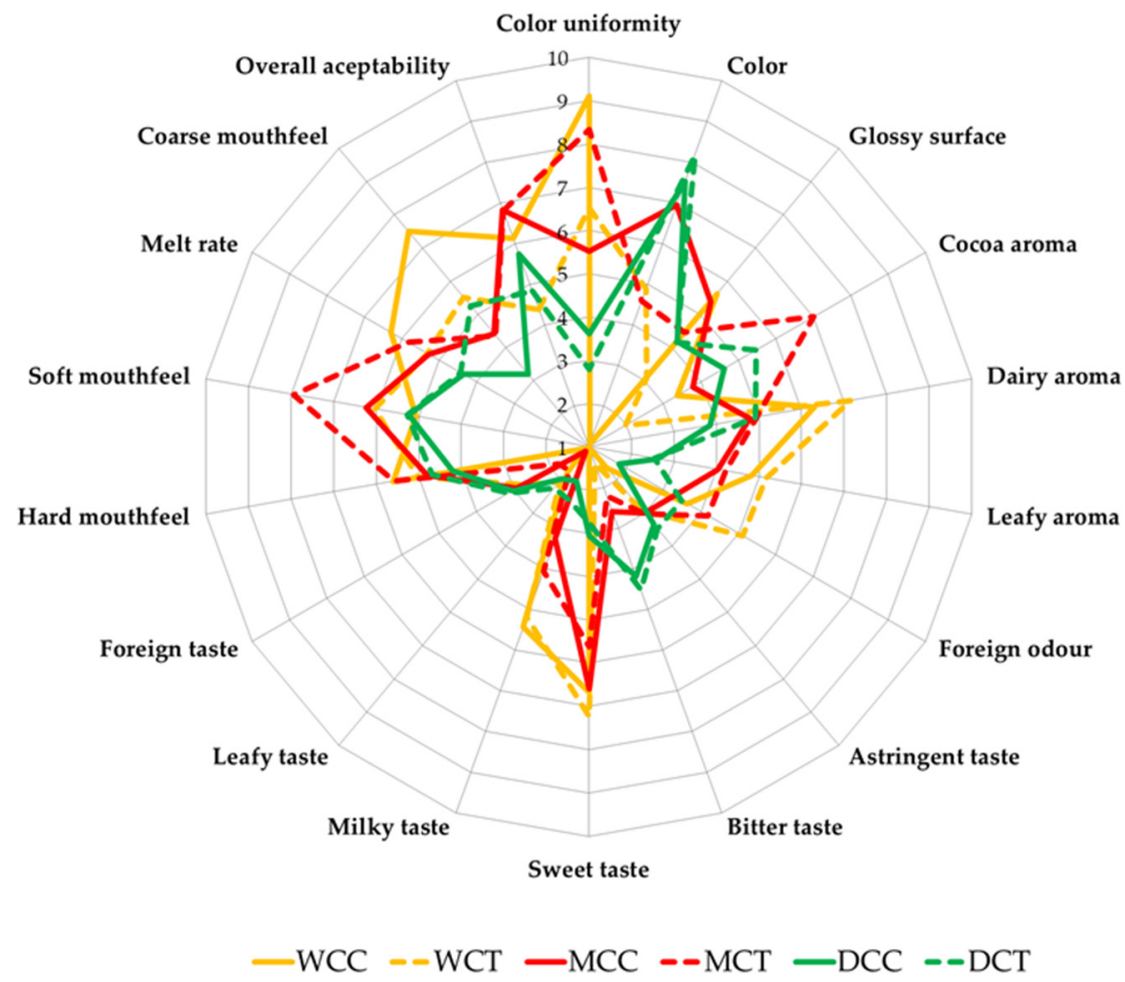

Figure 3. Radar chart with average consumer assessment results obtained by scaling method for white, milk and bitter chocolates with the addition of yellow tea extract $(0.2 \%)$; WCC-white chocolate control; WCT—white chocolate with tea; MCC — milk chocolate control; MCT—milk chocolate with tea; DCC—dark chocolate control; DCT—dark chocolate with tea.

The appearance of the chocolates, including the uniformity of the color on the surface, was the highest for white chocolate without tea extract addition: 9.1 on a scale from 1 to 10 . The lowest uniformity, according to the respondents, was characteristic for dark chocolate with $0.2 \%$ yellow tea extract (2.8). The color of the chocolate was characterized by the greatest differentiation among the distinguishing features. Dark chocolate with an addition 
was rated the most brown (8.2), and white chocolate with no additive as the cream color (1.1). The vast majority of chocolates were rated as not glossy on the surface, because their scores were below 5.0. Only the control white chocolate and the control milk chocolate were rated at 5.6 and 5.4 points of 10 points scale. The aroma features defined as cocoa, dairy, leafy and foreign aroma were evaluated as imperceptible (1.0) to intense (10.0). It was found that the addition of yellow tea extract caused an intensification of the aromas compared to the samples without the additive. The highest values for cocoa aroma were recorded for milk chocolate enriched with tea extract (7.0) and dark chocolate with tea (5.7) in the case of dairy aroma white chocolate with tea extract (7.2) and white chocolate (6.3). The leafy aroma resulted in a lower assessment of all the samples with the addition of tea, but these values were insignificantly higher than the controls and rated as imperceptible (1.1-2.2). Yellow tea extract, the additional source of polyphenols in our chocolates, showed that the "foreign" aroma negatively influenced the acceptance of the products. Probably, the leafy and astringent aftertaste was perceived.

The taste features defined as astringent, bitter, sweet, milky, leafy and foreign taste were evaluated as imperceptible (1.0) to intense (10.0). It was found that the addition of yellow tea extract did not influence the astringent and bitter taste of chocolates in comparison to the control samples. As expected, these undesirable organoleptic properties were slightly higher with increasing cocoa content and were highest for dark chocolate. The perception of sweet taste was higher for white and milk chocolate with yellow tea (7.2) in comparison to dark chocolate (2.8). It was found that the addition of yellow tea extract caused an intensification of the leafy taste for approximately $20 \%$, however, it did not influence the foreign taste occurrence, except the white chocolate (2.8) as compared with control sample (1.1). The mouthfeel features defined as hard, soft, coarse and melt rate were evaluated. Results showed that the addition of yellow tea extract softened the mouthfeel of chocolates where the lower values indicated crumbly chocolate (white chocolate and dark) and higher values indicated the malleable consistency (milk chocolate with tea). The melt rate of chocolates has not changed significantly in the presence of tea extract. The highest intensity of coarse mouthfeel was evaluated in white chocolate control and with tea extract (7.5 and 5.5, respectively) and dark chocolate with tea extract (5.3).

The best results of overall acceptability were observed in samples of milk chocolate with and without tea extract addition (6.9 and 6.8, respectively). The remaining chocolates with addition of tea extract obtained $17 \%$ lower consumer ratings in comparison to control samples. No chocolate was rated as not liked. The supplemented chocolates were well accepted by the panelists; however, higher overall acceptability was noted for milk chocolate.

\subsection{Storage Influence on Total Phenolic Content and Antioxidant Properties of Designed Confectionery}

The samples of chocolate with an addition of yellow tea extract were tested for antioxidant activity in free radical tests (DPPH ${ }^{\bullet}$ and $\mathrm{ABTS}^{\bullet+}$ ) and ORAC test during 6 months of storage at ambient temperature. The obtained results are presented in Figure 4. $\mathrm{DPPH}^{\bullet}$ and ABTS $^{\bullet+}$ as stable radicals are widely used to evaluate the antioxidant activity of various compounds and thus acting as antioxidants [62]. All analyzed samples showed higher activity in DPPH radical scavenging compared to ABTS assay. The highest activity toward radical, measured in Trolox (Tx) equivalents, was found in samples of dark chocolates, which were found to differ significantly between other samples $(p<0.05)$. 

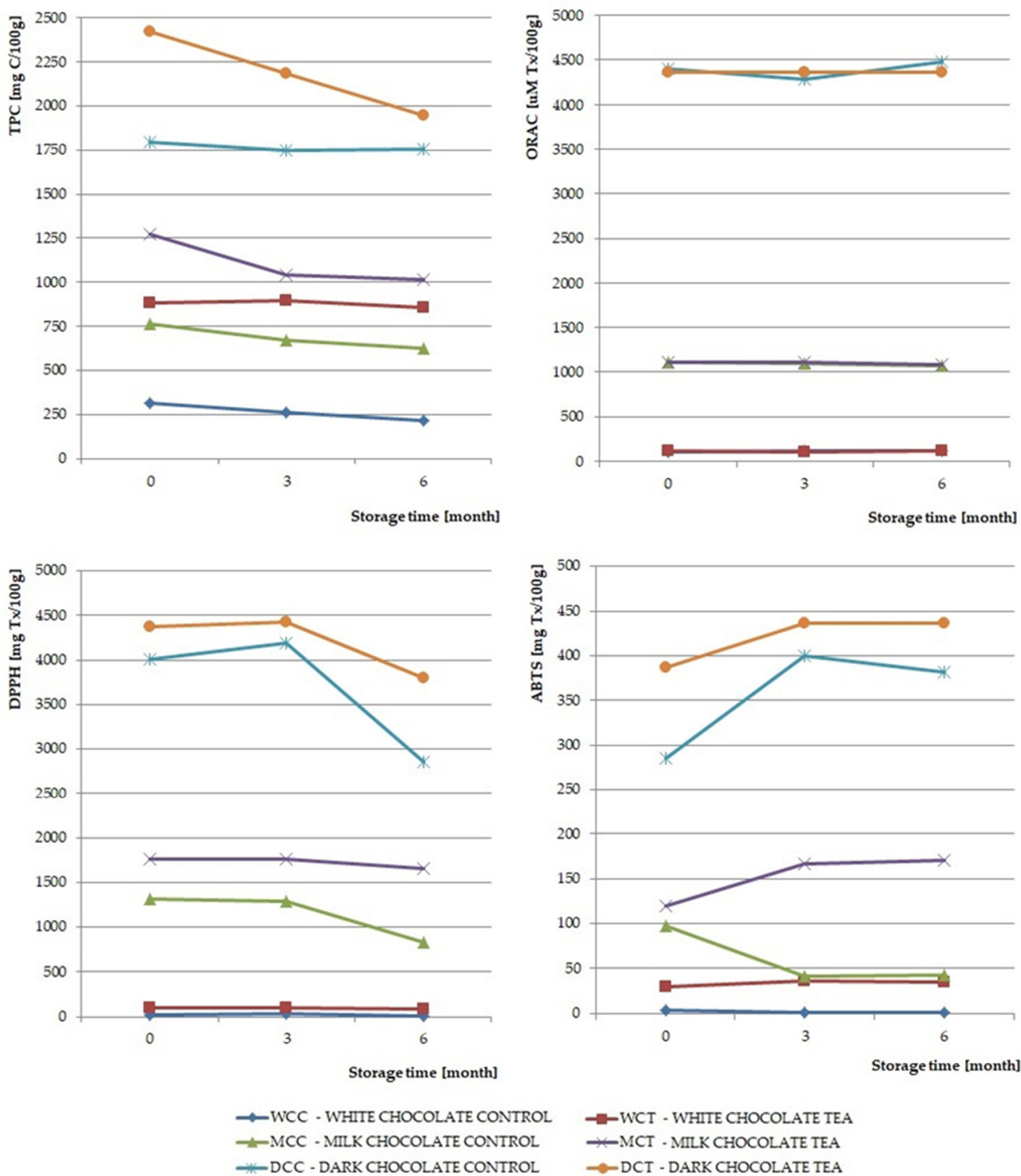

Figure 4. Antioxidant activity of white, milk and dark chocolate extracts with $0.2 \%$ addition of yellow tea extract during storage.

The results demonstrate that the addition of yellow tea extract powder was a successful attempt at increasing the antioxidant potential of enriched chocolates. The highest activity in scavenging the DPPH radical was determined for the samples of dark chocolate with yellow tea (4373 mg Tx/100 g) and the control sample (4012 $\mathrm{g}$ of Tx/100 g). The lowest activity was found for the control sample of white chocolate (23 mg Tx/100 g) and white chocolate with yellow tea extract (100 mg Tx/100 g). Among the samples of chocolates, a decrease in anti-radical activity was observed with the storage time $(p \leq 0.05)$. The DPPH radical scavenging activity decreased the most in samples stored for 6 months without the addition of yellow tea, and by $87 \%$ for WCC, $37 \%$ for MCC, and $29 \%$ for DCC. In the chocolates with the addition of yellow tea extract, the above decrease in anti-radical activity was significantly lower $(p<0.05)$ and amounted to $5 \%(\mathrm{MCT}), 13 \%$ (DCT) and 14\% (MCT).

ABTS radical cation scavenging activity showed the opposite trend compared to DPPH assay within examined samples. The highest activity was determined for the samples of dark chocolate with yellow tea (386 mg Tx/100 g) and without additive (285 g of Tx/100 g). The lowest activity was found for the white chocolate $(3.7 \mathrm{mg} \mathrm{Tx} / 100 \mathrm{~g})$ and white chocolate with yellow tea extract (30 mg Tx/100 g). The storage time of chocolate samples resulted in the significant increase of anti-radical activity $(p<0.05)$. The ABTS radical scavenging 
activity increased the most in samples stored for 6 months with the addition of yellow tea, and amounted to $43 \%$ for MCT, $14.8 \%$ for WCT, and $12.8 \%$ for DCT. In the chocolates without the addition of yellow tea extract, decrease in anti-radical activity was evaluated (64\% for WCC, and 56\% for MCC), only in dark chocolate an increase of $34 \%$ scavenging activity was noticed.

The highest ORAC value was evaluated for the samples of dark chocolate with yellow tea $(4363 \mu \mathrm{M}$ Tx/100 g) and without additive (4403 $\mu \mathrm{M}$ of Tx/100 g). The lowest value was found for the white chocolate $(107 \mu \mathrm{M} \mathrm{Tx} / 100 \mathrm{~g})$ and white chocolate with yellow tea extract $(110 \mu \mathrm{M} \mathrm{Tx} / 100 \mathrm{~g})$. The results showed no significant loss of oxygen radical scavenging ability during 6 months of chocolate samples storage $(p>0.05)$. Stable oxygen radical absorbance capacity could be a result of beneficial confectionery product composition which, besides yellow tea leaves extract, also included cocoa butter and cocoa solids, known for their high antioxidative potential [14].

Summarizing, the highest antioxidant activities were evaluated for the chocolates supplemented with $0.2 \%$ of yellow tea extract, at both DPPH and ABTS assay, however no changes were present in ORAC assay, regardless of chocolate kind and 6 months of storage. Therefore, it was noticed that yellow tea extract increased the amount of compounds reacting with Folin-Ciocalteu phenolic reagent, which may indirectly indicate antioxidant activity. Total content of phenolic compounds differed depending on the type of chocolate and was as follows: bitter (DCC) > milk (MCC) > white (WCC). The addition of $0.2 \%$ yellow tea extract increased the initial content of these compounds by an average of $283 \%$ for white (WCT), 166\% for milk (MCT) and 135\% for dark chocolate (DCT) (Figure 3). During the storage of chocolates, a decrease in the content of phenolic compounds was noted, however the highest losses were found in the samples with the addition of tea extract stored for 6 months. The highest losses were evaluated in samples of MCT (20\%), DCT $(19 \%)$, and the lowest WCT (3\%) as compared to fresh samples. That effect may indicate interactions between chocolate compounds and those contained in yellow tea extract. The results of the statistical analysis showed that the calculated correlation indicates a high relationship between the DPPH radicals scavenging activity and the content of phenolic compounds determined by the TPC assay ( $\mathrm{r} 2=0.981, p \leq 0.05$ ). A similar correlation was found between the results of ABTS and TPC assay ( $\mathrm{r} 2=0.784, p \leq 0.05$ ). Moreover, the calculated correlation shows no relationship between the results obtained with the ORAC assay and TPC ( $p \geq 0.05)$.

Yellow tea extract increased total polyphenols content in tested chocolate samples, however did not protect them from lipid oxidation process (Figure 5). There are no studies in the literature where the antioxidant activity of yellow tea extract in chocolates has been tested, which was the main subject of this study. Results showed that addition of tea extract enhanced antioxidant activity regardless of chocolate kind and was stabile during three months of storage, then activity found to be decreased in all samples except white chocolate. During storage, the peroxide value was evaluated and an increase in the level of primary lipid oxidation products was found in all tested samples. It was confirmed that the addition of yellow tea extract slowed down the lipid oxidation process during 6 months of storage. The rate of oxidation process inhibition in the chocolates fortified with yellow tea components was $50 \%$ for milk, $42 \%$ for dark and $12 \%$ for white chocolate compared to pure chocolates. 


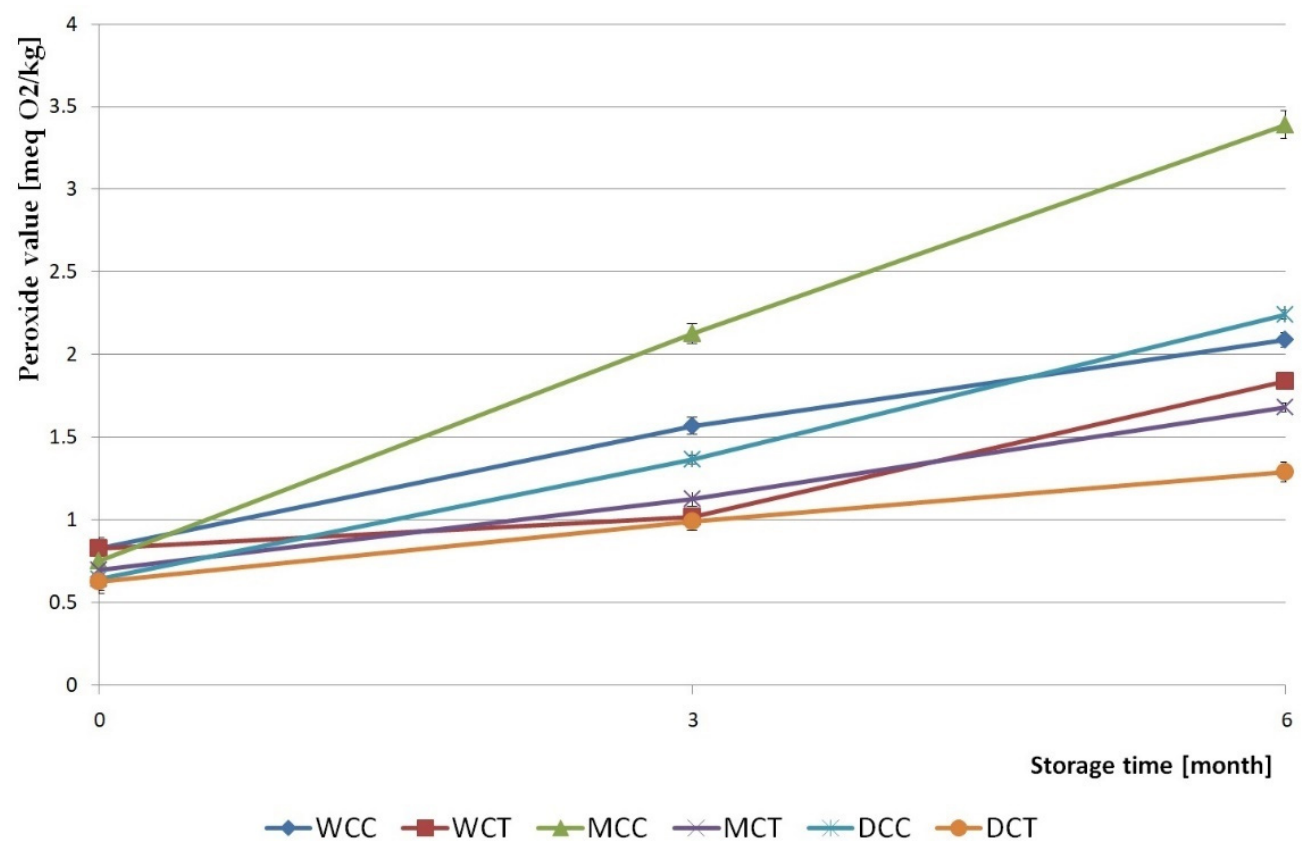

Figure 5. Peroxide value of white, milk and dark chocolate extracts with $0.2 \%$ addition of yellow tea extract during storage; WCC—white chocolate control; WCT—white chocolate with tea; MCC—milk chocolate control; MCT—milk chocolate with tea; DCC—dark chocolate control; DCT—dark chocolate with tea.

\subsection{Cholinesterases (ChE) Inhibition by Designed Confectionery}

The confectionery products, different chocolates with yellow tea extract, were characterized in terms of their capacity to inhibit the activity of cholinoesterases (ChEs), i.e., acetylocholinoesterase (AChE) and butyrylcholinoesterase (BChE) (Figure 6). The inhibition capacity of chocolates with and without addition of yellow tea extract was expressed as eserine equivalents per $1 \mathrm{~g}$ of product. Results showed that all chocolates exhibited cholinesterases inhibition capacity in a concentration-dependent manner. Confectionery products inhibited $\mathrm{AChE}$ to a greater extent than $\mathrm{BChE}$. In the initial stage of storage, it was dark chocolate without addition and milk chocolate with yellow tea that inhibited $\mathrm{AChE}$ to the greatest extent, while white chocolate with and without addition to the lowest degree. Total capacity to inhibit $\mathrm{AChE}$ differed depending on the type of chocolate and was as follows: $\mathrm{WCT}=\mathrm{WCC}<\mathrm{MCT}=\mathrm{DCT}=\mathrm{MCC}<\mathrm{DCC}$. However, the 6-month storage influenced the AChE inhibitory capacity for dark and milk chocolate, both with yellow tea. The lowest activity was found for white chocolate with the addition of yellow tea. After the end of storage, total capacity to inhibit $\mathrm{AChE}$ was as follows: $\mathrm{WCT}<\mathrm{MCT}=\mathrm{DCC}=$ MCC $<$ WCC $<$ DCT.

The assessment of the activity of the chocolates against $\mathrm{BChE}$ showed different trends. Before the storage, it was dark chocolate and milk chocolate with yellow tea and milk chocolate without additive that inhibited $\mathrm{BChE}$ to the greatest extent, while, similarly to AChE capacity, white chocolate with and without addition to the lowest degree. Total capacity to inhibit $\mathrm{BChE}$ differed depending on the type of chocolate and was as follows: WCT $=$ WCC $<$ DCC $<$ DCT $=$ MCC $<$ MCT. Further storage resulted in changes of the $\mathrm{BChE}$ inhibitory capacity for examined chocolates. Completion of the 6-month storage process resulted in the following sequence: $\mathrm{WCT}<\mathrm{WCC}<\mathrm{DCC}=\mathrm{DCT}<\mathrm{MCT}=\mathrm{MCC}$. 

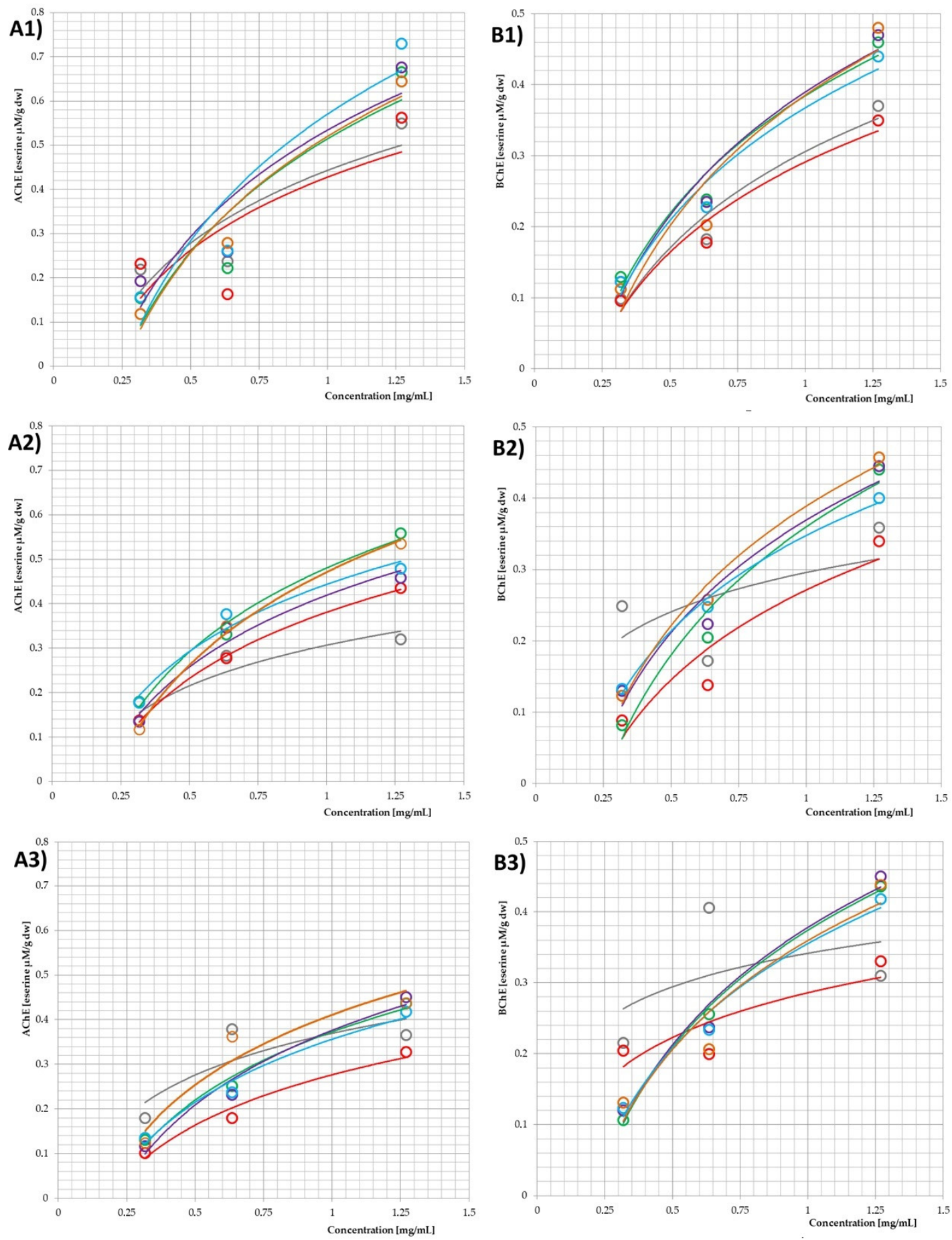
O WCC - white chocolate control
O WCT - white chocolate with tea
O MCC - milk chocolate control
O MCT - milk chocolate with tea
O DCC - dark chocolate control
DCT - dark chocolate with tea

Figure 6. Activity of designed chocolates with yellow tea extract as an acetylcholinesterase (A) and butyrylcholinesterase (B) inhibitors during storage (1-not stored; 2-3rd month, 3-6th month).

\section{Discussion}

Functional food production is becoming more and more popular. This food is dedicated to various social problems related to nutrition, e.g., people exposed to stress. Enriching food with plant extracts is very common, but adding green tea ingredients, especially matcha powder used in tea ceremonies, is very popular in Japan $[63,64]$. The truth is that 
it was Japan that inspired many to use powdered tea as an addition to numerous food products, including chocolate [65-69].

Today's consumer is looking for additives that are natural, perceived as safe and, moreover, introduce pro-health compounds into the product, increasing its functionality [70]. One of best-studied plants are tea leaves (Camelia sinensis L.), known for their sensory and outstanding pro-health value, but also for their strong antioxidant properties. The value of tea results from the compounds present, among which are polyphenols, commonly known as flavonols or catechins [71]. Antioxidant properties of tea preparations are due to the presence of catechins: (-)-epigallocatechin (EGC), (-)-epicatechin (EC), (-)- -catechin (C), (-)-epicatechin gallate (ECG), (-)-epigallocatechin gallate (EGCG) [64]. The individual composition of tea leaves differs with production technique and fermentation process conditions [21]. Yellow tea next to green and black starts to be appreciated by the science. Tea leaves manufacturing processes differ within the region and type of tea. The main division is based on the degree of leaves fermentation, which recognizes white and green (non-fermented), yellow (partly fermented), oolong (semi-fermented), and black tea (fully fermented) [72]. The processing of tea leaves consists of several steps including withering, rolling, fermentation, postfermentation and drying [21,73]. The main active components of tea leaves are flavan-3-ols, phenolic acids, tannins (condensed and hydrolysable), and purine alkaloids, which after processing go through several steps leading to the formation of theaflavins, thearubigins, and flavan-3-ols derivatives with a corresponding decrease in catechins concentrations [74]. Results indicate that yellowing time, a key factor in yellow tea processing, improves quality and biological activity of the final product $[75,76]$. Yellow tea has numerous health-promoting values, which mainly come from the presence of flavonoids and offer antioxidant, antihyperglycemic, antihyperlipidemic, and anticancer activity [75,77-80]. Yellow tea exhibits strong antioxidant activity in in vitro systems, e.g., fats, emulsions, foods and other systems [39,58,80-82]. Although epigallocatechin-3-gallate (EGCG) is the most studied catechin in the group of secondary metabolites of tea, the results showed however that its bioavailability was reduced since most of EGCG was not absorbed in intestinal and blood environment $[83,84]$. Despite the fact that EGCG is a very powerful antioxidant, research has indicated that it is pure compounds that can exhibit toxic effects, which was not found in water extracts from tea leaves $[85,86]$. Therefore, it was found that the appropriate addition of aqueous extract, which is a concentrated infusion, is safe.

Previous studies have focused on phenolic content and antioxidant activity of yellow tea and chocolate either separately or mixed with other ingredients, but no research has been found combining these two products. The functional properties of tea and chocolate have encouraged the development of products and their combination as confectionery shown to be a promising market [87]. New formulations need the quantitative characterization of the sensory features of the product with the participation of trained panel and proper principles of the study. In present study, the addition of $0.2 \%$ yellow tea extracts into white chocolate showed that aroma, color, texture, and overall acceptability were highly scored in comparison to other concentrations. Therefore, this concentration was decided for subsequent testing, which was applied in white, milk and bitter chocolate samples.

Today's market strategy for the development of innovative food products is primarily focused on a positive perception by the consumer, especially in terms of sensory values. Therefore, in our research we used different chocolates in order to reflect the possible ability to mask the sensory properties, mostly bitterness of yellow tea extract. The consumer analysis covering quality related properties including visual, and sensory attributes, as well as overall acceptability of enriched chocolates showed satisfactory rating of all the products, however milk chocolate was the highest rated.

Results of our studies showed that functional additive of yellow tea extract accounting for $0.2 \%$ of dry mass of chocolates did not influence the basic chemical composition, however it significantly influenced total polyphenols content (TPC) in all the samples $(p<0.05)$. Therefore, it was noticed that the amount of phenolic compounds significantly shaped the 
antioxidant activity of enriched chocolates $(p<0.05)$. Other studies have confirmed that the antioxidant capacity of tea and chocolate could be a result of favorable composition of polyphenolic compounds such as flavonoids $[14,25]$. Therefore, it is promising to enrich the product with ingredients derived from yellow tea leaves, which may increase the supply of these compounds in the diet.

Polyphenols are plant origin antioxidants which control or prevent the oxidation process by scavenging of radicals [88]. General classification of antioxidants include primary and secondary natural antioxidants, differing within the mechanism of action [89]. Primary antioxidants, including phytochemicals as flavonoids present in coca and tea, are the chain breaking antioxidants donating the electrons and reacting with lipid radicals, and therefore converting them into more stable products. Secondary antioxidants include phenolic compounds performing the function of capturing free radicals, chain reaction catalysts, and therefore stopping the chain reactions. Antioxidants such as polyphenols may be present in foods as endogenous agents or may be added in order to preserve their lipid components from deterioration. BHA (butylated hydroxyanisole), BHT (butylated hydroxytoluene) or PG (propyl gallate) are synthetic antioxidants commonly used in food products, however, due to safety concerns, the attention of today's consumer is focused on natural antioxidants perceived as safe, but nevertheless requiring further safety research [90]. To meet the consumer's needs, herbal extracts such as tea extracts have been widely commercialized for applications in food and nutraceutical [91]. However, it should not also be forgotten that plant extracts are the mixture of different properties constituents, which is why its antioxidant activity could vary according to the reaction environment [92] All of tea polyphenols, particularly catechins, possess antioxidant activity; however, it particularly depends on its proportions [93]. Partially fermented yellow tea consists of, e.g., catechins, gallic acid and theaflavins, which are more effective in bulk oils [94]. However, studies show that many phenolic antioxidants can also exhibit pro-oxidant behavior under certain conditions dependent on solubility characteristics, chelating behavior or $\mathrm{pH}[95,96]$.

Present research found that all the tested samples showed higher activity in DPPH radical scavenging compared to ABTS assay. The highest activity toward radical, measured in Trolox equivalents, was found in samples of dark chocolates, which differed significantly from other samples $(p<0.05)$. Our results of ABTS and DPPH radical scavenging assay demonstrate that the addition of yellow tea extract powder increased the antioxidant potential of enriched chocolates. As expected, based on the content of active ingredients in chocolates, anti-radical activity of those enriched with tea product was correlated with polyphenol content. The highest activity in DPPH and ABTS assay was determined for the samples of dark chocolate with yellow tea, and did not decrease significantly during storage. What was also found is that ORAC value was highest for the samples of dark chocolate with yellow tea, and six months of storage did not result in significant loss of oxygen radical scavenging ability. The literature values for tea and chocolate ORAC capacity are high, nevertheless, observing the results from our study in ORAC values, no increase in total antioxidant capacity that would result from the addition of yellow tea extract was observed. The obtained effect may suggest that the above activity is masked by the fat present in the chocolate. Results of Żyżelewicz et al. examined the chocolates with addition of cocoa liquor from roasted beans and concluded that the cocoa liquor type used induced minor changes in the polyphenol and fatty acid composition [97]. Moreover, they found that those chocolates were characterized by the highest DPPH radicals scavenging activity. However, contrary to our research, they also found that antioxidant activity determined by the ORAC-FL method increased with increasing polyphenol content in the chocolates. Todorovic et al. examined the addition of raspberries to dark chocolates [98]. Results showed no influence on total polyphenol, flavonoid and proanthocyanidin contents in the chocolates, statistical analysis, however, showed significant increase $(p<0.05)$ in the antioxidant capacity evaluated in ABTS, DPPH and ORAC assay, of dark chocolates with raspberry compared to plain dark chocolates. 
Progressive neurodegenerative disease is mainly characterized by abnormally low levels of the neurotransmitter acetylcholine in the brain, therefore acetylcholinesterase (AChE) and butyrylcholinesterase $(\mathrm{BChE})$ inhibitors are promising tools in the treatment process of Alzheimer's disease [99]. Research shows that tea components serve as a rich source of cholinesterase inhibitors, mainly EGCG, which play a significant role in Alzheimer's disease treatment by enhancing of cholinergic neurotransmission $[30,100]$. There are studies which evidence that cocoa and tea flavonoids can acutely improve cognitive function in humans, by means of increased cerebral blood flow [101,102]. Lamport et al. research showed that dark chocolate ( $70 \%$ of cocoa) consumption has a positive effect on verbal episodic memory, confirming that everyday consumption of dark chocolate benefits to the brain in healthy consumers [102]. As the research shows, consuming cocoa beans has a beneficial effect on cardiovascular diseases. In human studies, ACE inhibition was found to be $18 \%$ on average. Based on the research, it was found that the consumption of chocolate with a high content of cocoa mass increases the inhibition of ACE activity, which was confirmed by in vitro and in vivo studies [103]. Inhibition of BChE is also important in the treatment of neurodegenerative diseases such as Alzheimer's disease. The conducted research indicates the inhibitory effect of tea polyphenols on BChE. It was also found that raw materials rich in flavonoids can be an excellent material for their production. This, in turn, could be used to compose drugs for neurodegenerative diseases [104].

Our results showed that cholinesterases inhibition capacity of chocolates with and without addition of yellow tea extract was greater for $\mathrm{AChE}$ than $\mathrm{BChE}$. Total capacity to inhibit AChE differed depending on the type of chocolate and was highest for dark chocolate. However, a negative effect of storage time was observed. The results of $\mathrm{BChE}$ inhibition showed similar trends. Due to the higher activity against $\mathrm{AChE}$ and $\mathrm{BChE}$ of chocolate with the addition of yellow tea compared to the control samples, yellow tea extract may be a potential functional food ingredient in the treatment of neurodegenerative diseases, including Alzheimer's disease. Therefore, the antioxidant potential and health-promoting properties of chocolate and tea ingredients described in the literature are probably sufficient justification for their use as bioactive food additives $[4,105]$.

Chocolate is one of the foods that contain high fat content [14]. Despite the fact that it contains polyphenolic compounds from cocoa, it undergoes the process of oxidation like other products. This process is particularly noticeable in chocolates containing lower amount of cocoa, e.g., white and milk chocolate. The lipid oxidation process is a free radical chain reaction leading to sudden increase in reactive radicals and hydroperoxides content and thereby further deterioration reactions [106]. The negative effect is mainly associated with the sensory properties' deterioration, e.g., change of color, consistency and rancidity, however the progress of this process significantly affects the nutritional value and increases the health risk [107]. One of the most efficient ways to protect lipid containing products is application of antioxidative components [108]. The presence of antioxidants allows to balance the chemical reactions, and therefore limit the unfavorable changes influencing the quality and stability of a final product. Carrizo et al. examined the antioxidant activity of tea chemicals as a packaging component, and showed that tea catechins could be incorporated in the adhesive applied for building the laminates [109]. They demonstrated good antioxidant performance and long shelf life of tested food, such as peanuts and cereals covered by chocolate, packed within the designed material. Jongberg et al. showed that green and Maté tea, rich in polyphenols, are a good source of antioxidants for protection of both lipids and proteins in chill-stored pork chops [110]. Our results showed that during storage the peroxide value increased in all tested samples, however, it was limited in samples enriched with the addition of yellow tea extract. Our previous research showed that tea extracts were good sources of antioxidants, and yellow tea extract affected the reduction of oil polymerization changes during frying [81]. 


\section{Conclusions}

The food market in the twentieth century is strongly interested and determined to give to the consumers tasty, inexpensive products, which apart from strong antioxidative activity would bring pro-health charge and functionality. The addition of yellow tea powdered extract had a certain effect on antioxidant capacity of enriched chocolates, which was first noticed as an increase in the total polyphenols content in the product. After 6 months of storage these features were affected according to applied assay. Yellow tea extract in different chocolates did not affect sensorial characteristics remarkably, but did affect visual and olfactory characteristics of enriched chocolates to varying degrees. Chocolates with tea extract exhibited a more attractive color, while their texture was slightly harder in comparison to the control sample. A stronger effect was observed in confectioneries obtained by addition of yellow tea extract into a dark chocolate. Confectioneries with tea extract addition exhibited better storage stability, what was especially important in the case of high level of fat where oxidative deterioration is most significant. The best effect was observed when yellow tea extract was used as additive in dark instead of white and milk chocolates. Recipe enrichment with yellow tea extract allowed to obtain confectioneries with acceptable sensory attributes and stable antioxidative quality during storage.

The results of the experiment showed that the addition of powdered tea extract into formulation used for confectionery preparation is a promising approach towards the improvement of the functionally of sweets and other confectionery products. Our findings provide a clue for the design of the functional products, however, further research considering the changes in polyphenolic compounds is required.

Author Contributions: A.G.-M., conceptualization, methodology, formal analysis, writing, review and edition, supervision, and funding acquisition; B.K., methodology, formal analysis, methodology, writing; M.S., formal analysis, methodology, writing; J.K.-C., formal analysis, methodology; A.B., formal analysis. All authors have read and agreed to the published version of the manuscript.

Funding: This research was funded by Poznan University of Life Sciences, Poland, Department of Gastronomy Science and Functional Foods (statutory grant no 506.751.03.00).

Institutional Review Board Statement: Ethical review and consent were waived for this study, because despite the fact that it was a human study, it was observational and the study design did not include the ethical issues.

Informed Consent Statement: Informed consent was obtained from all subjects involved in the study.

Data Availability Statement: Data are contained within the article.

Conflicts of Interest: The authors declare no conflict of interest.

\section{References}

1. World Health Organization (WHO). Obesity. Available online: https://www.who.int/news-room/facts-in-pictures/detail/6facts-on-obesity (accessed on 10 March 2021).

2. World Health Organization (WHO). Diabetes. Available online: https://www.who.int/news-room/fact-sheets/detail/diabetes (accessed on 10 March 2021).

3. Wickramasuriya, A.M.; Dunwell, J.M. Cacao biotechnology: Current status and future prospects. Plant Biotechnol. J. 2018, 16, 4-17. [CrossRef] [PubMed]

4. Nowak, E.; Livney, Y.D.; Niu, Z.; Singh, H. Delivery of bioactives in food for optimal efficacy: What inspirations and insights can be gained from pharmaceutics? Trends Food Sci. Technol. 2019, 91, 557-573. [CrossRef]

5. Visioli, F.; Bernaert, H.; Corti, R.; Ferri, C.; Heptinstall, S.; Molinari, E.; Poli, A.; Serafini, M.; Smit, H.; Vinson, J.; et al. Chocolate, lifestyle, and health. Crit. Rev. Food Sci. Nutr. 2009, 49, 299-312. [CrossRef] [PubMed]

6. Meier, B.; Noll, S.; Molokwu, O. The sweet life: The effect of mindful chocolate consumption on mood. Appetite 2017, 108, 21-28. [CrossRef] [PubMed]

7. Gunaratne, T.M.; Fuentes, S.; Gunaratne, N.M.; Torrico, D.D.; Gonzalez Viejo, C.; Dunshea, F.R. Physiological responses to basic tastes for sensory evaluation of chocolate using biometric techniques. Foods 2019, 8, 243. [CrossRef]

8. Lattimore, P. Mindfulness-based emotional eating awareness training: Taking the emotional out of eating. Eat. Weight Disord. 2020, 25, 649-657. [CrossRef] 
9. Belšcak-Cvitanović, A.; Komes, D.; Benoković, M.; Karlović, S.; Hecimović, I.; Ježek, D.; Bauman, I. Innovative formulations of chocolates enriched with plant polyphenols from Rubus idaeus L. leaves and characterization of their physical, bioactive and sensory properties. Food Res. Int. 2012, 48, 820-830. [CrossRef]

10. Chetana, R.; Reddy, S.; Negi, P. Preparation and properties of probiotic chocolates using yoghurt powder. Food Nutr. Sci. 2013, 4, 276-281. [CrossRef]

11. De Morais, E.C.; Lima, G.C.; de Morais, A.R.; André Bolini, H.M. Prebiotic and diet/light chocolate dairy dessert: Chemical composition, sensory profiling and relationship with consumer expectation. LWT Food Sci. Technol. 2015, 62, 424-430. [CrossRef]

12. Sim, S.Y.; Ng, J.W.; Ng, W.K.; Forde, C.G.; Henry, C.J. Plant polyphenols to enhance the nutritional and sensory properties of chocolates. Food Chem. 2016, 200, 46-54. [CrossRef]

13. Lončarević, I.; Pajin, B.; Fišteš, A.; Tumbas Šaponjac, V.; Petrović, J.; Jovanović, P.; Vulić, J.; Zarić, D. Enrichment of white chocolate with black-berry juice encapsulate: Impact on physical properties, sensory characteristics and polyphenol content. LWT Food Sci. Technol. 2018, 92, 458-464. [CrossRef]

14. Gutiérrez, T.J. State-of-the-art chocolate manufacture: A review. Compr. Rev. Food Sci. Food Saf. 2017, 16, 1313-1344. [CrossRef]

15. Montagna, M.T.; Diella, G.; Triggiano, F.; Caponio, G.R.; Giglio, O.D.; Caggiano, G.; Ciaula, A.D.; Portincasa, P. Chocolate, “Food of the Gods": History, science, and human health. Int. J. Environ. Res. Public Health 2019, 16, 4960. [CrossRef] [PubMed]

16. Gramza-Michałowska, A.; Sidor, A.; Kulczyński, B. Methylxanthines in Food Products. In Analytical Methods in the Determination of Bioactive Compounds and Elements in Food. Food Bioactive Ingredients; Jeszka-Skowron, M., Zgoła-Grześkowiak, A., Grześkowiak, T., Ramakrishna, A., Eds.; Springer: Cham, Switzerland, 2021; pp. 83-100. [CrossRef]

17. De Araujo, Q.R.; Gattward, J.N.; Almoosawi, S.; Silva, M.D.; Dantas, P.A.; De Araujo Júnior, Q.R. Cocoa and human health: From head to foot-A review. Crit. Rev Food Sci. Nutr. 2016, 6, 1-12. [CrossRef]

18. Seem, S.A.; Yuan, Y.V.; Tou, J.C. Chocolate and chocolate constituents influence bone health and osteoporosis risk. Nutrition 2019, 65, 74-84. [CrossRef] [PubMed]

19. Kord-Varkaneh, H.; Ghaedi, E.; Nazary-Vanani, A.; Mohammadi, H.; Shab-Bidar, S. Does cocoa/dark chocolate supplementation have favorable effect on body weight, body mass index and waist circumference? A systematic review, meta-analysis and dose-response of randomized clinical trials. Crit. Rev. Food Sci. Nutr. 2019, 59, 2349-2362. [CrossRef]

20. Zugravu, C.; Otelea, M.R. Dark chocolate: To eat or not to eat? A review. J. AOAC Int. 2019, 102, 1388-1396. [CrossRef]

21. Zhang, L.; Ho, C.-T.; Zhou, J.; Santos, J.S.; Armstrong, L.; Granato, D. Chemistry and biological activities of processed Camellia sinensis teas: A comprehensive review. Comp. Rev. Food Sci. Food Saf. 2019, 18, 1474-1495. [CrossRef]

22. Khan, N.; Mukhtar, H. Tea polyphenols in promotion of human health. Nutrients 2019, 11, 39. [CrossRef]

23. Tang, G.-Y.; Zhao, C.-N.; Xu, X.-Y.; Gan, R.-Y.; Cao, S.-Y.; Liu, Q.; Shang, A.; Mao, Q.-Q.; Li, H.-B. Phytochemical composition and antioxidantc of 30 Chinese teas. Antioxidants 2019, 8, 180. [CrossRef]

24. McAlpine, M.D.; Ward, W.E. Influence of steep time on polyphenol content and antioxidant capacity of black, green, rooibos, and herbal teas. Beverages 2016, 2, 17. [CrossRef]

25. Zhao, C.-N.; Tang, G.-Y.; Cao, S.-Y.; Xu, X.-Y.; Gan, R.-Y.; Liu, Q.; Mao, Q.-Q.; Shang, A.; Li, H.-B. Phenolic profiles and antioxidant activities of 30 tea infusions from green, black, oolong, white, yellow and dark teas. Antioxidants 2019, 8, 215. [CrossRef] [PubMed]

26. Paiva, L.; Rego, C.; Lima, E.; Marcone, M.; Baptista, J. Comparative analysis of the polyphenols, caffeine, and antioxidant activities of green tea, white tea, and flowers from Azorean Camellia sinensis varieties affected by different harvested and processing conditions. Antioxidants 2021, 10, 183. [CrossRef] [PubMed]

27. Chupeerach, C.; Aursalung, A.; Watcharachaisoponsiri, T.; Whanmek, K.; Thiyajai, P.; Yosphan, K.; Sritalahareuthai, V.; Sahasakul, Y.; Santivarangkna, C.; Suttisansanee, U. The effect of steaming and fermentation on nutritive values, antioxidant activities, and inhibitory properties of tea leaves. Foods 2021, 10, 117. [CrossRef] [PubMed]

28. Soh, A.Z.; Pan, A.; Chee, C.B.E.; Wang, Y.-T.; Yuan, J.-M.; Koh, W.-P. Tea drinking and its association with active tuberculosis incidence among middle-aged and elderly adults: The Singapore Chinese health study. Nutrients 2017, 9, 544. [CrossRef]

29. Mao, X.; Xiao, X.; Chen, D.; Yu, B.; He, J. Tea and its components prevent cancer: A review of the redox-related mechanism. Int. J. Mol. Sci. 2019, 20, 5249. [CrossRef]

30. Baranowska-Wójcik, E.; Szwajgier, D.; Winiarska-Mieczan, A. Regardless of the brewing conditions, various types of tea are a source of acetylcholinesterase inhibitors. Nutrients 2020, 12, 709. [CrossRef]

31. Cao, S.-Y.; Li, B.-Y.; Gan, R.-Y.; Mao, Q.-Q.; Wang, Y.-F.; Shang, A.; Meng, J.-M.; Xu, X.-Y.; Wei, X.-L.; Li, H.-B. The in vivo antioxidant and hepatoprotective actions of selected Chinese teas. Foods 2020, 9, 262. [CrossRef]

32. Lin, S.-Y.; Kan, J.Y.; Lu, C.-C.; Huang, H.H.; Cheng, T.-L.; Huang, H.-T.; Ho, C.-J.; Lee, T.-C.; Chuang, S.-C.; Lin, Y.-S.; et al. Green tea catechin (-)-epigallocatechin-3-gallate (EGCG) facilitates fracture healing. Biomolecules 2020, 10, 620. [CrossRef]

33. Lu, X.; Saeed, M.E.M.; Hegazy, M.-E.F.; Kampf, C.J.; Efferth, T. Chemopreventive property of sencha tea extracts towards sensitive and multidrug-resistant leukemia and multiple myeloma cells. Biomolecules 2020, 10, 1000. [CrossRef]

34. Reale, S.; Flint, S.W. The impact of menu label design on visual attention, food choice and recognition: An eye tracking study. J. Sens. Stud. 2016, 31, 328-340. [CrossRef]

35. Sharma, A.; Zhou, W. A stability study of green tea catechins during the biscuit making process. Food Chem. 2011, 126, 568-573. [CrossRef]

36. Budryn, G.; Żyżelewicz, D.; Nebesny, E.; Oracz, J.; Krysiak, W. Influence of addition of green tea and green coffee extracts on the properties of fine yeast pastry fried products. Food Res. Int. 2013, 50, 149-160. [CrossRef] 
37. Aslani, A.; Ghannadi, A.; Khalafi, Z. Design, formulation and evaluation of green tea chewing gum. Adv. Biomed. Res. 2014, 3. [CrossRef] [PubMed]

38. Aroyeun, S.O.; Jayeola, C.O. Effects of green tea extracts on the caffeine, tannin, total polyphenolic contents and organoleptic properties of milk chocolate. J. Food Proces. Technol. 2016, 7, 1000579. [CrossRef]

39. Gramza-Michałowska, A.; Kobus-Cisowska, J.; Kmiecik, D.; Korczak, J.; Helak, B.; Dziedzic, K.; Górecka, D. Antioxidative potential, nutritional value and sensory profiles of confectionery fortified with green and yellow tea leaves (Camellia sinensis). Food Chem. 2016, 211, 448-454. [CrossRef]

40. Yüksel, A.K.; Yüksel, M.; Şat, I.G. Determination of certain physicochemical characteristics and sensory properties of green tea powder (matcha) added ice creams and detection of their organic acid and mineral contents. GIDA 2017, 42, 116-126. [CrossRef]

41. Kumari, S.; Raj, J.D.; Shukla, R.N. Study of quality \& antioxidant properties of green tea doughnut. J. Pharmacogn. Phytochem. 2018, 7, 3101-3106.

42. De, B.; Bhandari, K.; Goswami, T.K. Tea diversification products and value addition. GJPPS 2019, 7. [CrossRef]

43. Lončarević, I.; Pajin, B.; Tumbas Šaponjac, V.; Petrović, J.; Vulić, J.; Fišteš, A.; Jovanović, P. Physical, sensorial and bioactive characteristics of white chocolate with encapsulated green tea extract. J. Sci. Food Agric. 2019, 99, 5834-5841. [CrossRef]

44. Choi, Y.; Kim, E.; Kim, H. Physicochemical and antioxidant properties of cookies prepared using powders of barley sprout, lemon balm, and green tea. J. Korean Soc. Food Cult. 2020, 35, 459-466. [CrossRef]

45. Swarnathilake, D.S.G.G.C.; Abeysinghe, D.C. Improving the quality and the taste of green tea ice cream by identifying suitable cultivar, agronomic practices and processing techniques of Assamica tea grown in Sri Lanka. WJARR 2020, 8, 62-68. [CrossRef]

46. Santos, J.S.; Leal, A.S.; Escher, G.B.; Cruz, A.G.; Cruz, T.M.; Hellström, J.; Pihlava, J.-M.; Granato, D. Effects of an herbal extract composed of white tea, roasted yerba mate and fermented rooibos on the antioxidant activity and sensory properties of popsicles manufactured with different protein sources. J. Food Bioact. 2020, 11, 1-11. [CrossRef]

47. Gramza-Michałowska, A.; Sidor, A.; Reguła, J.; Kulczyński, B. PCL assay application in superoxide anion-radical scavenging capacity of tea camellia sinensis extracts. Acta Sci. Pol. Technol. Aliment. 2015, 14, 331-341. [CrossRef] [PubMed]

48. Polish Standard PN-EN ISO 8589:2010. Sensory Analysis-General Guidelines for Designing a Sensory Analysis Laboratory; ISO: Geneva, Switzerland, 2010.

49. Polish Standard PN-EN ISO 8586:2014-03. Sensory Analysis-General Guidelines for the Selection, Training and Monitoring of Selected Assessors and Sensory Evaluation Experts; ISO: Geneva, Switzerland, 2014.

50. Lawless, H.T.; Heymann, H. Scaling. In Sensory Evaluation of Food; Lawless, H.T., Heymann, H., Eds.; Food Science Text Series; Springer: Boston, MA, USA, 1999; pp. 149-177. [CrossRef]

51. ISO 1442:1997. Meat and Meat Products. Determination of Moisture Content; ISO: Geneva, Switzerland, 1997.

52. AOAC. Official Methods of Analysis: Official Method for Protein; Method No. 920.87; Association of Official Analytical Chemists: Washington, DC, USA, 1995.

53. AOAC. Official Methods of Analysis: Official Method for Ash; Method No. 936.03; Association of Official Analytical Chemists: Washington, DC, USA, 2000.

54. Regulation (EU) No 1169/2011 of the European Parliament and of the Council of 25 October 2011 on the Provision of Food Information to Consumers, Amending Regulations (EC) No 1924/2006 and (EC) No 1925/2006 of the European Parliament and of the Council, and Repealing Commission Directive 87/250/EEC, Council Directive 90/496/EEC, Commission Directive 1999/10/EC, Directive 2000/13/EC of the European Parliament and of the Council, Commission Directives 2002/67/EC and 2008/5/EC and Commission Regulation (EC) No 608/2004. Available online: https:/ / eur-lex.europa.eu/legal-content/EN/ TXT/PDF/?uri=CELEX:32011R1169\&from=EN (accessed on 26 February 2021).

55. Gramza-Michałowska, A.; Bueschke, M.; Kulczyński, B.; Gliszczyńska-Świgło, A.; Kmiecik, D.; Bilska, A.; Purłan, M.; Wałęsa, L.; Ostrowski, M.; Filipczuk, M.; et al. Phenolic compounds and multivariate analysis of antiradical properties of red fruits. J. Food Meas. Charact. 2019, 13, 1739-1747. [CrossRef]

56. Sánchez-Moreno, C.; Larrauri, J.A.; Saura-Calixto, F. A procedure to measure the antiradical efficiency of polyphenols. J. Sci. Food Agric. 1998, 76, 270-276. [CrossRef]

57. Re, R.; Pellegrini, N.; Proteggente, A.; Pannala, A.; Yang, M.; Rice-Evans, C. Antioxidant activity applying an improved ABTS radical cation decolorization assay. Free Radic. Biol. Med. 1999, 26, 1231-1237. [CrossRef]

58. Gramza Michałowska, A.; Kmiecik, D.; Kobus-Cisowska, J.; Żywica, A.; Dziedzic, K.; Brzozowska, A. Phytonutrients in oat (Avena sativa L.) drink-Effect of plant extract on antiradical capacity, nutritional value and sensory characteristics. Pol. J. Food Nutr. Sci. 2017, 68. [CrossRef]

59. Polish Standard PN-EN ISO 3960: 2009. Animal and Vegetable Oils and Fats. Determination of Peroxide Value; ISO: Geneva, Switzerland, 2009.

60. Ellman, G.L.; Courtney, K.D.; Andres, V.; Featherstone, R.M. A new and rapid colorimetric determination of acetylcholinesterase activity. Biochem. Pharmacol. 1961, 7, 88-95. [CrossRef]

61. Kobus-Cisowska, J.; Szymanowska, D.; Maciejewska, P.; Kmiecik, D.; Gramza-Michałowska, A.; Kulczyński, B.; Cielecka-Piontek, J. In Vitro screening for acetylcholinesterase and butyrylcholinesterase inhibition and antimicrobial activity of chia seeds (Salvia hispanica). Electron. J. Biotechnol. 2019, 37, 1-10. [CrossRef]

62. Ácsová, A.; Martiniaková, S.; Hojerová, J. Selected in vitro methods to determine antioxidant activity of hydrophilic/lipophilic substances. Acta Chim. Slovaca 2019, 12, 200-211. [CrossRef] 
63. Iwatani, S.; Yamamoto, N. Functional food products in Japan: A review. Food Sci. Hum. Wellness 2019, 8, 96-101. [CrossRef]

64. Kochman, J.; Jakubczyk, K.; Antoniewicz, J.; Mruk, H.; Janda, K. Health benefits and chemical composition of matcha green tea: A review. Molecules 2020, 26, 85. [CrossRef]

65. Lu, T.M.; Lee, C.C.; Mau, J.L.; Lin, S.D. Quality and antioxidant property of green tea sponge cake. Food Chem. 2010, 119, 1090-1095. [CrossRef]

66. Ahmad, M.; Baba, W.N.; Wani, T.A.; Gani, A.; Gani, A.; Shah, U.; Wani, S.M.; Masoodi, F.A. Effect of green tea powder on thermal, rheological and functional properties of wheat flour and physical, nutraceutical and sensory analysis of cookies. J. Food Sci. Technol. 2015, 52, 5799-5807. [CrossRef]

67. Gramza-Michalowska, A.; Kulczynski, B.; Yuan, X.; Gumienna, M. Research on the effect of culture time on the kombucha tea beverage's antiradical capacity and sensory value. Acta Sci. Pol. Technol. Aliment. 2016, 15, 447-457. [CrossRef]

68. Phongnarisorn, B.; Orfila, C.; Holmes, M.; Marshall, L.J. Enrichment of biscuits with matcha green tea powder: Its impact on consumer acceptability and acute metabolic response. Foods 2018, 7, 17. [CrossRef] [PubMed]

69. Yu, K.; Zhou, H.-M.; Zhu, K.-X.; Guo, X.-N.; Peng, W. Water cooking stability of dried noodles enriched with different particle size and concentration green tea powders. Foods 2020, 9, 298. [CrossRef] [PubMed]

70. Bogue, J.; Collins, O.; Troy, A.J. Market analysis and concept development of functional foods. In Developing New Functional Food and Nutraceutical Products; Bagchi, D., Nair, S., Eds.; Academic Press: Cambridge, MA, USA, 2017; pp. 29-45. [CrossRef]

71. Sanlier, A.; Gokcen, B.B.; Altuğ, M. Tea consumption and disease correlations. Trends Food Sci. Technol. 2018, 78, 95-106. [CrossRef]

72. Ning, J.; Li, D.; Luo, X.; Ding, D.; Song, Y.; Zhang, Z.; Wan, X. Stepwise identification of six tea (Camellia sinensis (L.) categories based on catechins, caffeine, and theanine contents combined with fisher discriminant analysis. Food Anal. Method. 2016, 9, 3242-3250. [CrossRef]

73. Guo, X.; Ho, C.T.; Schwab, W.; Wan, X. Effect of the roasting degree on flavor quality of large-leaf yellow tea. Food Chem. 2021, 347, 129016. [CrossRef] [PubMed]

74. Wang, Z.; Yue, C.; Tong, H. Analysis of taste characteristics and identification of key chemical components of fifteen Chinese yellow tea samples. J. Food Sci. Technol. Mysore 2020, 58, 1378-1388. [CrossRef] [PubMed]

75. An, R.; Sun, L.; Xiang, L.; Zhang, W.; Li, Q.; Lai, X.; Wen, S.; Huo, M.; Li, D.; Sun, S. Effect of yellowing time on bioactive compounds in yellow tea and their antiproliferative capacity in HepG2 cells. Food Sci. Nutr. 2019, 7, 1838-1847. [CrossRef]

76. Wei, Y.; Li, T.; Xu, S.; Ni, T.; Deng, W.W.; Ning, J. The profile of dynamic changes in yellow tea quality and chemical composition during yellowing process. LWT Food Sci. Technol. 2020, 139, 110792. [CrossRef]

77. Han, M.; Zhao, G.; Wang, Y.; Wang, D.; Sun, F.; Ning, J.; Wan, X.; Zhang, J. Safety and anti-hyperglycemic efficacy of various tea types in mice. Sci. Rep. 2016, 6, 31703. [CrossRef]

78. Kujawska, M.; Ewertowska, M.; Adamska, T.; Ignatowicz, E.; Gramza-Michałowska, A.; Jodynis-Liebert, J. Protective effect of yellow tea extract on N-nitrosodiethylamine-induced liver carcinogenesis. Pharm. Biol. 2016, 3, 1-10. [CrossRef]

79. Teng, Y.; Li, D.; Guruvaiah, P.; Xu, N.; Xie, Z. Dietary supplement of large yellow tea ameliorates metabolic syndrome and attenuates hepatic steatosis in $\mathrm{db} / \mathrm{db}$ mice. Nutrients 2018, 10, 75. [CrossRef]

80. Xu, J.; Wang, M.; Zhao, J.; Wang, Y.; Tang, Q.; Khan, I.A. Yellow tea (Camellia sinensis L.), a promising Chinese tea: Processing, chemical constituents and health benefits. Food Res. Int. 2018, 107, 567-577. [CrossRef]

81. Kmiecik, D.; Gramza-Michałowska, A.; Korczak, J. Anti-polymerization activity of tea and fruits extracts during rapeseed oil heating. Food Chem. 2018, 239, 858-864. [CrossRef] [PubMed]

82. Piechocka, J.; Szymandera-Buszka, K.; Kobus-Cisowska, J.; Gramza-Michałowska, A.; Jędrusek-Golińska, A. The effect of thiamine concentration on the antioxidative activity indices in tea extracts. Antioxidants 2019, 8, 555. [CrossRef]

83. Legeay, S.; Rodier, M.; Fillon, L.; Faure, S.; Clere, N. Epigallocatechin gallate: A review of its beneficial properties to prevent metabolic syndrome. Nutrients 2015, 7, 5443-5468. [CrossRef]

84. Dai, W.; Ruan, C.; Zhang, Y.; Wang, J.; Han, J.; Shao, Z.; Sun, Y.; Liang, J. Bioavailability enhancement of EGCG by structural modification and nano-delivery: A review. J. Funct. Foods 2020, 65, 103732. [CrossRef]

85. Kucera, O.; Mezera, V.; Moravcova, A.; Endlicher, R.; Lotkova, H.; Drahota, Z.; Cervinkova, Z. In Vitro toxicity of epigallocatechin gallate in rat liver mitochondria and hepatocytes. Oxid. Med. Cell. Longev. 2015, 476180. [CrossRef]

86. Kujawska, M.; Ewertowska, M.; Ignatowicz, E.; Adamska, T.; Szaefer, H.; Gramza-Michałowska, A.; Korczak, J.; Jodynis-Liebert, J. Evaluation of safety and antioxidant activity of yellow tea (Camellia sinensis) extract for application in food. J. Med. Food 2016, 19, 330-336. [CrossRef] [PubMed]

87. Annunziata, A.; Vecchio, R. Functional foods development in the European market: A consumer perspective. J. Funct. Foods 2011, 3, 223-228. [CrossRef]

88. Rasouli, H.; Farzaei, M.H.; Khodarahmi, R. Polyphenols and their benefits: A review. Int. J. Food Propert. 2017, $20,1700-1741$. [CrossRef]

89. Couttolenc, A.; Díaz-Porras, Á.; Espinoza, C.; Medina, M.E.; Trigos, Á. On the primary and secondary antioxidant activity from hydroxy-methylcoumarins: Experimental and theoretical studies. J. Phys. Org. Chem. 2020, 33, e4025. [CrossRef]

90. Wilson, D.W.; Nash, P.; Buttar, H.S.; Griffiths, K.; Singh, R.; De Meester, F.; Horiuchi, R.; Takahashi, T. The Role of Food Antioxidants, Benefits of Functional Foods, and Influence of Feeding Habits on the Health of the Older Person: An Overview. Antioxidants 2017, 6, 81. [CrossRef] 
91. Gramza-Michałowska, A.; Hęś, M.; Korczak, J. Tea extracts antioxidative potential in emulsified lipid systems. Acta Sci. Pol. Technol. Aliment. 2008, 7, 29-34.

92. Gramza, A.; Khokhar, S.; Yoko, S.; Gliszczynska-Swiglo, A.; Hes, M.; Korczak, J. Antioxidant activity of tea extracts in lipids and correlation with polyphenol content. Eur. J. Lipid Sci. Technol. 2006, 108, 351-362. [CrossRef]

93. Frankel, E.N.; Huang, S.W.; Kanner, J.; German, J.B. Interfacial phenomena in the evaluation of antioxidants: Bulk oils vs emulsions. J. Agric. Food Chem. 1994, 42, 1054-1059. [CrossRef]

94. Decker, A. Phenolics: Prooxidants or Antioxidants? Nutr. Rev. 1997, 55, 396-398. [CrossRef] [PubMed]

95. Salehi, B.; Martorell, M.; Arbiser, J.L.; Sureda, A.; Martins, N.; Maurya, P.K.; Sharifi-Rad, M.; Kumar, P.; Sharifi-Rad, J. Antioxidants: Positive or Negative Actors? Biomolecules 2018, 8, 124. [CrossRef] [PubMed]

96. Sajilata, M.; Bajaj, P.R.; Singhal, R. Tea Polyphenols as Nutraceuticals. Compr. Rev. Food Sci. Food Saf. 2008, 7, 229-254. [CrossRef]

97. Żyżelewicz, D.; Budryn, G.; Oracz, J.; Antolak, H.; Kregiel, D.; Kaczmarska, M. The effect on bioactive components and characteristics of chocolate by functionalization with raw cocoa beans. Food Res. Int. 2018, 113, 234-244. [CrossRef] [PubMed]

98. Todorovic, V.; Radojcic Redovnikovic, I.; Todorovic, Z.; Jankovic, G.; Dodevska, M.; Sobajic, S. Polyphenols, methylxanthines, and antioxidant capacity of chocolates produced in Serbia. J. Food Comp. Anal. 2015, 41, 137-143. [CrossRef]

99. Polito, C.A.; Cai, Z.-Y.; Shi, Y.-L.; Li, X.-M.; Yang, R.; Shi, M.; Li, Q.-S.; Ma, S.-C.; Xiang, L.-P.; Wang, K.-R.; et al. Association of tea consumption with risk of Alzheimer's disease and anti-beta-amyloid effects of tea. Nutrients 2018, 10, 655. [CrossRef]

100. Ali, B.; Jamal, Q.M.S.; Shams, S.; Al-Wabel, N.A.; Siddiqui, M.U.; Alzohairy, M.A.; Al Karaawi, M.A.; Kesari, K.K.; Mushtaq, G.; Kamal, M.A. In silico analysis of green tea polyphenols as inhibitors of AChE and BChE enzymes in Alzheimer's disease treatment. CNS Neurol. Disord. Drug 2016, 15, 624-628. [CrossRef]

101. Ma, Q.P.; Huang, C.; Cui, Q.Y.; Yang, D.J.; Sun, K.; Chen, X.; Li, X.H. Meta-analysis of the association between tea intake and the risk of cognitive disorders. PLoS ONE 2016, 11, e0165861. [CrossRef]

102. Lamport, D.J.; Christodoulou, E.; Achilleos, C. Beneficial effects of dark chocolate for episodic memory in healthy young adults: A parallel-groups acute intervention with a white chocolate control. Nutrients 2020, 12, 483. [CrossRef]

103. Persson, I.A.; Persson, K.; Hagg, S.; Andersson, R.G. Effects of cocoa extract and dark chocolate on angiotensin-converting enzyme and nitric oxide in human endothelial cells and healthy volunteers-A nutrigenomics perspective. J. Cardiovasc. Pharmacol. 2011, 57, 44-50. [CrossRef] [PubMed]

104. Katalini, M.; Bosak, A.; Kovarik, Z. Flavonoids as inhibitors of human butyrylcholinesterase variants. Food Technol. Biotechnol. 2014, 52, 64-67.

105. Ide, K.; Matsuoka, N.; Yamada, H.; Furushima, D.; Kawakami, K. Effects of tea catechins on alzheimer's disease: Recent updates and perspectives. Molecules 2018, 23, 2357. [CrossRef] [PubMed]

106. Frankel, E.N. Lipid Oxidation; The Oily Press: Dundee, UK, 1998.

107. Wąsowicz, E.; Gramza, A.; Hęś, M.; Jeleń, H.H.; Korczak, J.; Małecka, M.; Mildner-Szkudlarz, S.; Rudzińska, M.; Samotyja, U.; Zawirska-Wojtasiak, R. Oxidation of lipids in food. Pol. J. Food Nutr. Sci. 2004, 13, 87-100.

108. Khan, M.K.; Ahmad, K.; Hassan, S.; Imran, M.; Ahmad, N.; Xu, C. Effect of novel technologies on polyphenols during food processing. Innov. Food Sci. Emerg. Technol. 2018, 45, 361-381. [CrossRef]

109. Carrizo, D.; Taborda, G.; Nerín, C.; Bosetti, O. Extension of shelf life of two fatty foods using a new antioxidant multilayer packaging containing green tea extract. Innov. Food Sci. Emerg. Technol. 2016, 33, 534-541. [CrossRef]

110. Jongberg, S.; Tørngren, M.A.; Skibsted, L.H. Dose-dependent effects of green tea or maté extracts on lipid and protein oxidation in brine-injected retail-packed pork chops. Medicines 2018, 5, 11. [CrossRef] 